УДК: $378-043.86: 323.2 .072 .1(477) “ 1991 / 2001 ”$

DOI:

Уляна Ткаченко, аспірант Хмельницької гуманітарно-педагогічної академї̈

\title{
РОЗВИТОК ВИЩОЇ ОСВІТИ В НЕЗАЛЕЖНІЙ УКРАЇНІ (1991 - 2002 РР.)
}

У статті розкрито особливості вищої освіти в Україні в період ї̈ незалежності (1991 - 2002 рр.). Показано законодавчу базу, зокрема Закон України "Про освіту", Держсавна національна програма "Освіта" (Україна ХХІ століття), Національна доктрина розвитку освіти та ін. Звернено увагу на основні напрями розвитку вищої освіти, як-от: особистісна орієнтація освіти; формування національних $і$ загальнолюдських цінностей; створення рівних можливостей для молоді у здобутті якісної освіти; розвиток системи неперервної освіти та освіти впродовж життя; формування за допомогою освіти здорового способу життя; розвиток україномовного освітнього простору; забезпечення економічних і соціальних гарантій для професійної самореалізаиії педагогічних, науково-педагогічних працівників, підвищення їхнього сочіального статусу; інтеграція освіти і науки, розвиток педагогічної та психологічної науки; розробка $і$ запровадження освітніх інновацій, інформаційних технологій; інтеграція української освіти у європейський та світовий освітній простір.

Ключові слова: вища освіта; Україна; період незалежності (1991 - 2002 рр.); розвиток; напрями; тенденції; принциипи.

Jim. 5.

Ulyana Tkachenko, Postgraduate Student of the Khmelnytskiy Humanitarian-Pedagogical Academy

\section{DEVELOPMENT OF HIGHER EDUCATION IN INDEPENDENT UKRAINE}

(1991 - 2002)

The article reveals the peculiarities of higher education in Ukraine during its independence (1991 - 2002). The legislative framework, in particular, the Law of Ukraine "On Education", the State National Program "Education" (Ukraine of the XXI century), the National Doctrine on Education Development, etc. has been shown. The attention is focused on the main directions of the development of higher education, such as: personal orientation of education; formation of national and universal values; creation of equal opportunities for youth in obtaining high-quality education; development of the system of continuous education and education throughout life; formation by means of education of a healthy way of life; development of the Ukrainian-language educational space; provision of economic and social guarantees for professional self-realization of pedagogical, scientific-pedagogical workers, increase of their social status; integration of education and science, development of pedagogical and psychological science; development and introduction of educational innovations, information technologies; integration of Ukrainian education into European and world educational space. The priorities of higher education in Ukraine, its principles and directions have also been determined. In particular, it is the training of people of high education and morals, qualified specialists capable of creative work, professional development, mastering and implementation of knowledge intensive and information technologies, mobility and competitiveness in the labor market; creation of the necessary conditions for the development of gifted youth; support of young people with special needs; upbringing of a healthy lifestyle, development of youth sports, tourism; ecological, legal, economic education and upbringing; succession and continuity of education; variety of types of educational institutions, variability of educational programs, individualization of education and upbringing; monitoring of educational process, increasing the quality of educational services; creation of conditions for effective professional activity, support of work capacity and preservation of health of pedagogical, scientific-pedagogical workers in accordance with their role in the society. Knowledge of peculiarities of the development of the higher education system of Ukraine, its considerable capacity and scientific potential will be able to provide further and rather rapid innovative development of this sphere.

Keywords: higher education; Ukraine; a period of independence (1991 - 2002); development; trends; tendencies; principles.

$\Pi$ остановка проблеми в загальному вигляді. Розвиток України утретьому тисячолітті визначається в контексті європейської інтеграції з орієнтацією на побудову громадянського суспільства. Протягом перших десятиліть державної незалежності в Україні здійснюється історично неминучий перехід до нових основ суспільного розвитку: у соціальнополітичній сфері - це перехід від тоталітаризму до демократії; в економіці - від адміністративно- командної системи планового господарства до соціально орієнтованої ринкової економіки; ужитті кожної людини - від споживацьких, споглядальних позицій до функцій самодостатнього суб'єкта діяльності. Такі зміни в суспільстві, економіці, освіті, життєвому устрої потребують відновлення соціальних пріоритетів самої особистості.

На зміну індустріальному суспільству приходить суспільство інформаційне, що визначає непересічні соціальні, виробничі, економічні й 
політичні зрушення. Вектор розвитку освіти спрямовується на якість, відновлення і розширення освітніх послуг. Відповідно до потреб економічного розвитку суспільства формується ринок праці, зростає чисельність працівників інформаційної сфери, розвиваються високі технології, збільшується число зайнятих у невиробничій сфері, з'являються нові професії.

Прискорення науково-технічного прогресу визначає підвищені вимоги до якісного потенціалу працівників, які займаються генеруванням, розробленням i впровадженням нових технологічних ідей. За умов трансформації українського суспільства особливої значимості набувають питання розвитку вищої освіти, формування особистістю нових життєвих стратегій, компетентності, посилення гнучкості й мобільності соціальної поведінки. Чим вищий рівень освіти людини, тим легше їй перебороти кризові ситуації, опанувати конструктивноперетворювальну позицію. Усе це висуває нові вимоги до інтелектуального рівня суспільства, удосконалення розвитку вищої освіти, професіоналізму, розпочатого в перші роки незалежності України [1].

Аналіз останніх досліджень і публікацій. Проблеми розвитку вищої освіти в Україні розглядали багато дослідників, зокремаВ. Андрущенко, I. Бех, Л. Ващенко, С. Гончаренко, І. Зязюн, В. Кремень, В. Мадзігон, І. Передерій, С. Сірополко, В. Шинкарук, М. Ярмаченко та ін.

Дослідженню професійної підготовки фахівців у вищій школі присвячені праці В. Байденко, Р. Гуревича, I. Доброскок, М. Євтуха, І. Зязюна, С. Лісової, С. Сисоєвої та ін. Історія та сучасні пріоритети вищої освіти досліджувались у працях вітчизняних науковців (Н. Бібік, А. Гармаш, Л. Губерський, В. Захарченко, М. Згуровський, С. Калашнікова, О. Локшина, В. Луговий, О. Пометун, Ю. Рашкевич, О. Савченко, М. Степко, М. Чобітько, Ю. Шапран та ін.) так і зарубіжних дослідників (Р. Болестер, Т. Навраксис, П. Рейлі, М. Рейхертс, А. Хербовська та ін.) [3].

Формулювання цілей статті. Мета статті - розкрити особливості розвитку вищої освіти України в період іiї незалежності (1991 - 2002 рр.), показати законодавчу базу, основні напрями, завдання та принципи вищої освіти у зазначений період.

Виклад основного матеріалу. Україна успадкувала від СРСР потужну розгалужену освітню систему 3 передовою на той час інфраструктурою. Водночас включення освіти України у загальносоюзну освітню систему мало негативні наслідки. Підготовка кадрів здебільшого була орієнтована на загальносоюзні потреби та плани, що призвело до диспропорції у розміщенні вищих навчальних закладів та в структурі фахових напрямків підготовки спеціалістів: при надмірній кількості фахівців 3 інженерною освітою не вистачало правовиків, економістів, соціологів, психологів, менеджерів.

Централізація розробки навчальних програм, підручників зумовила уніфікацію навчального процесу, що обмежувало можливість вивчення історії, культури, України та їі окремих регіонів. Адміністративно-командна система управління освітою гальмувала розвиток педагогічної творчості, обмежувала ініціативу. Усі ці обставини вимагали ретельного аналізу й оновлення системи освіти, іiі модернізації. За якісними та кількісними показниками вона не завжди відповідає рівню освіти країн Європи та світу, має застарілий зміст, форми і методи навчання, інші перешкоди і проблеми. Для того, щоб сучасна вища українська освіта була конкурентоспроможною, досягла світового рівня, необхідно усунути ці перешкоди і проблеми, а також провести всебічний аналіз минулого, досконало знати досвід історичного розвитку вищої освіти в Україні. Тільки знання попередніх систем освіти, їх негативних i позитивних сторін дозволить бути сучасній українській системі вищої освіти найбільш доцільною і досконалою.

Зазначений етап розвитку вищої освіти в України почався після проголошення ï незалежності. У цей період в країні відроджуються і впроваджуються кращі надбання та досвід систем Радянської вищої освіти та країн Європи. За останні роки в Україні було прийнято низку документів, спрямованих на подальший розвиток системи вищої освіти. Це Державна національна програма “Освіта. Україна ХХІ століття” (1993 р.), Закон України “Про освіту” (1991р.), Закон України "Про вищу освіту” (2002р.).

Концептуальні основи і державні пріоритети розвитку освіти в Україні з перших років іiі незалежності, розглядаються передусім з позицій iii ролі й місця в забезпеченні життєдіяльності суспільства, безпосереднього взаємозв'язку зі сферою праці. 3 цією метою ведеться активна системна робота зі створення умов для визначення освітніх проблем розвитку країни та її регіонів у політичному контексті і прийняття рішень на державному рівні, вирішення проблем із залученням сфери освіти, що виникають на ринку праці, надання системі вищої освіти широких можливостей для одержання громадянами професійної підготовки [2].

Підходи і практичні дії щодо розвитку системи 
освіти в Україні базуються на концепції побудови незалежної демократичної держави, пріоритетами якої є доступ до освіти та професійної підготовки усіх, хто має необхідні здібності, мотивацію й адекватну підготовку, використання вищої освіти та професійної підготовки для захисту соціальних інтересів суспільства, зменшення монопольних прав держави в освітній сфері за рахунок створення на рівноправній основі недержавних навчально-виховних, професійно технічних і навчальних закладів, формування різноманітної інвестиційної політики в галузі освіти. Визначальними при цьому є забезпечення всебічної готовності громадян до одержання освіти будь-якого рівня і створення умов для задоволення освітніх і професійних потреб особистості 3 можливістю удосконалення здобутих знань впродовж усього життя, у тому числі шляхом перепідготовки й підвищення кваліфікації.

Основними шляхами реформування системи освіти визначено: створення в суспільстві атмосфери загально-державного сприяння розвитку освіти; подолання девальвації загальнолюдських і гуманістичних цінностей, відриву від національних джерел; забезпечення розвитку вищої освіти на основі нових прогресивних концепцій, упровадження передових технологій і науково-методичних досягнень; підготовку нової генерації педагогічних кадрів; інтеграцію освіти і науки; активне залучення до навчального процесу наукового потенціалу вищих навчальних закладів; мотивацію до участі в наукових дослідженнях і розробках.

За роки незалежності України на державному рівні у складних умовах перехідного періоду було створено законодавче освітнє правове поле. 3 прийняттям Конституції України, законів України “Про освіту”, “Про дошкільну освіту”, "Про загальну середню освіту”, “Про позашкільну освіту", "Про професійно-технічну освіту", "Про вищу освіту" були визначені основні правові норми демократичного розвитку системи освіти [4].

На основі нової законодавчої бази в Україні в складних соціально-економічних умовах здійснюється цілеспрямована робота щодо стабілізації системи освіти, створення належних умов для організації діяльності вищих навчальних закладів, реалізується політика пріоритетної державної підтримки вищої освіти, цільових програм навчання здібних i обдарованих студентів, а також студентів $з$ особливими потребами. Зроблені також істотні кроки щодо утвердження безперервної ступеневої освіти, створення вітчизняної науково-педагогічної літератури, оновлення змісту освіти та професійної підготовки, забезпечення варіативності мережі навчальних закладів та освітніх стандартів, розширення економічної бази вищої освіти.

Концептуальні засади іiі реформи визначено Державною національною програмою “Освіта (Україна XXI століття)”. Цей документ, був розглянутий і схвалений Першим з’їздом педагогічних працівників України (грудень 1992 р.) і затверджений Кабінетом Міністрів (постанова № 896 від 3 листопада 1993 р.).

Реалізація програми передбачала досягнення якісно нового стану освіти, iіi інтеграцію у міжнародний освітній простір. Програмою визначено шляхи забезпечення пріоритетного розвитку освіти України, в тому числі вищої, залучення до активної участі в цьому процесі всіх державних та громадських інституцій, приватних структур, трудових колективів, сімей, кожного громадянина.

Одне 3 найголовніших завдань - орієнтація освіти на задоволення освітніх потреб кожної особи з урахуванням національно-культурних прав і запитів усіх громадян країни незалежно від їх етнічної належності. Це здійснювалось шляхом оновлення змісту вищої освіти, його взаємоузгодження на всіх освітніх рівнях, впровадження передових педагогічних концепцій і технологій, врахування кращого вітчизняного та світового досвіду, формування нової генерації педагогічних кадрів.

Важливими вимогами реформування було подолання державної монополії в галузі освіти та диверсифікації освітніх програм, урізноманітнення джерел фінансування і демократизація форм управління, створення навчальних закладів різних типів [2].

Основні напрями державної політики у сфері вищої освіти визначені Конституцією України, законами України "Про освіту" та "Про вищу освіту”, актами Президента України та Кабінету Міністрів України.

Законом України “Про вищу освіту" врегульовуються суспільні відносини у галузі навчання, виховання, професійної підготовки громадян України. Він встановлює правові, організаційні, фінансові та інші засади функціонування системи вищої освіти, створює умови для самореалізації особистості, забезпечення потреб суспільства і держави у кваліфікованих фахівцях.

Державна політика у галузі вищої освіти визначається Верховною Радою України і грунтується на принципах: доступності здобуття вищої освіти кожним громадянином України; 
незалежності від впливу політичних партій, громадських і релігійних організацій; інтеграції системи вищої освіти України у світову систему при збереженні й розвитку досягнень і традицій української вищої школи; державної підтримки підготовки фахівців для пріоритетних напрямів фундаментальних i прикладних наукових досліджень.

Зазначені принципи забезпечуються шляхом: збереження і розвитку системи вищої освіти та підвищення їі якості; підвищення рівня освіченості громадян України, їх можливостей для отримання вищої освіти; створення та забезпечення рівних умов доступності до вищої освіти; надання цільових пільгових державних кредитів особам для здобуття вищої освіти; забезпечення збалансованої структури та обсягів підготовки фахівців з вищою освітою з урахуванням потреб особи, а також інтересів держави та територіальних громад.

Законом визначено, що громадяни України мають право безоплатно здобувати вищу освіту в державних і комунальних вищих навчальних закладах на конкурсній основі в межах стандартів вищої освіти, якщо певний освітньокваліфікаційний рівень громадянин здобуває вперше. Вони вільні у виборі форми здобуття вищої освіти, вищого навчального закладу, напряму підготовки і спеціальності.

Вища освіта України, як і все суспільство, перебуває в процесі демократизації взаємовідносин на всіх рівнях функціонування галузі. Удосконаленню правового поля у сфері демократизації вищої школи сприяє Закон України "Про вищу освіту" визначені принципи автономії вищих навчальних закладів, централізація та децентралізація процесу прийняття управлінських рішень [4].

Також передбачено право закладу вищої освіти самостійно визначати форми навчання та види організації навчально-виховного процесу, самостійно розробляти та запроваджувати власні програми наукової та науково-виробничої діяльності, удосконалювати організаційну структуру, створюючи певні структурні підрозділи (інститути, коледжі, технікуми, факультети, відділення філії тощо). Введено в дію нову процедуру обрання керівників вищих навчальних закладів. Претенденти на посаду керівника обираються вищим колегіальним органом громадського самоврядування вищого навчального закладу (конференцією або зборами трудового колективу) таємним голосуванням.

Демократичність та участь громадськості найбільше виявляється в таких сферах, як розробка складових системи стандартів вищої освіти, формування концепції ступеневої освіти, доступ до вищої освіти громадян України.

Демократизація галузі освіти забезпечує більш широкі можливості молоді для вступу до вищих навчальних закладів і більш повного розкриття іiі здібностей. Основними засадами і факторами, що обумовили їх виникнення, є: демократизація суспільства, формування нових соціальноекономічних структур, орієнтованих на ринкові відносини, жорстка професійна конкуренція; відповідно до ступеневої освіти підготовка фахівців орієнтована на мобільність і мінливість соціальної і виробничої діяльності; забезпечення випускникам можливості здійснювати професійну кар'єру на основі принципів соціальної справедливості; диференціація вимог до характеру і змісту освіти та професійної підготовки фахівців з вищою освітою різних освітньо-кваліфікаційних рівнів; також впровадження об'єктивного педагогічного контролю при визначенні результатів діяльності вищого навчального закладу.

Результати розбудови національної системи вищої освіти за десять років незалежності України проаналізовано на II Всеукраїнському з'їзді працівників освіти (2001р.), ії подальшу стратегію визначено у Національній доктрині розвитку освіти, яка є державним документом, що визначає систему поглядів на стратегію і основні напрями розвитку освіти в Україні у першій чверті XXI ст.

Відповідно до Доктрини освіта є основою розвитку особистості, суспільства, нації та держави. Вона $є$ визначальним чинником суспільства, його політичної, соціальноекономічної, культурної і наукової організації. Освіта відтворює і нарощує інтелектуальний, духовний і економічний потенціал народу, виховує патріота і громадянина України. Також вона $є$ важливим напрямом забезпечення національних інтересів, конкурентоспроможності української держави на міжнародній арені, на світовому ринку високих технологій [5].

За роки незалежності на основі Конституції України в державі визначено нові пріоритети розвитку освіти, створено відповідну правову базу, розпочато практичне реформування галузі згідно 3 Державною національною програмою “Освіта (Україна XXI століття)”. Першочергові зусилля держави направлені на розширення доступності якісної освіти впродовж життя для всіх громадян, забезпечення національного характеру освіти. Також здійснюється постійне оновлення змісту вищої освіти відповідно до демократичних цінностей, ринкових засад розвитку економіки, сучасних наукових досягнень. 
Політика особливої державної підтримки дошкільної, середньої, професійно-технічної освіти у сільській місцевості, навчання здібних та обдарованих учнів і студентів, а також дітей 3 особливими потребами реалізується через цільові державні програми “Вчитель”, “Шкільний автобус”, “Комп’ютеризація сільської школи”, "Обдаровані діти” тощо.

Зусилля органів державного управління також спрямовані на докорінне зміцнення та оновлення навчально-наукової матеріальної бази, комп'ютеризацію вищих навчальних закладів, впровадження інформаційних технологій, забезпечення сучасних підходів до перепідготовки і підвищення кваліфікації кадрів [1].

Висновки. XXI ст. висуває до освіти нові вимоги. Для вирішення важливих питань європейської інтеграції потрібне загальне уявлення про історію та перспективи розвитку системи вищої освіти України 3 урахуванням ㄲï особливостей.

Після здобуття незалежності в суверенній Україні почала формуватися та втілюватися в життя власна політика в галузі освіти, спрямована на досягнення сучасного рівня якості та доступності, відродження національних традицій, докорінне оновлення змісту, форм і методів навчання, примноження інтелектуального потенціалу України.

Глобалізація, швидка зміна технологій, утвердження пріоритетів сталого розвитку суспільства зумовлюють зростання ролі вищої освіти. Життя в умовах демократії, ринку, новітніх науково-інформаційних технологій стає невідворотною перспективою. Все це робить своєрідний виклик освіті, зумовлює потребу їі радикальної модернізації за рахунок прискореного, випереджувального інноваційного розвитку, забезпечення умов для самоствердження i самореалізації особистості впродовж життя.

Вища освіта $є$ могутнім чинником розвитку духовної культури українського народу, відтворення продуктивних сил суспільства. Ця гуманітарна сфера спрямована на забезпечення фундаментальної наукової, загальнокультурної, професійної підготовки особистості, формування інтелектуального потенціалу нації і всебічний розвиток особистості як найвищої цінності суспільства.

Таким чином, розвиток вищої освіти в Україні у період незалежності надає уявлення про хід освітніх процесів у майбутньому, дозволяє спроектувати діяльність вищих навчальних закладів таким чином, щоб вони були конкурентоспроможними як на рівні Свропи, так і на світовому рівні. Знання особливостей розвитку системи вищої освіти України, іiі значної потужності й наукового потенціалу зможуть забезпечити подальший і досить швидкий інноваційний розвиток цієї сфери.

Перспективи подальших розвідок у даному напрямі. Перспективи подальших розвідок щодо розвитку вищої освіти України у період незалежності (1991 - 2002 рр.) ми вбачаємо у аналізі та використанні позитивного досвіду цього періоду для удосконалення сучасної вищої української освіти в період євроінтеграції, тощо.

\section{ЛІТЕРАТУРА}

1. Вища освіта в Україні: навчальний посібник / за заг.ред. В.Г.Кременя, С.М.Ніколаєнка. Київ, $2005.327 \mathrm{c}$.

2. Історія вищої освіти в Україні. URL: http:// ua-referat.com/

3. Касьянов Г. Освітня система України 19902014. Аналітичний огляд. Київ, 2015. 52 с.

4. Кривчик Г. Г. Вища школа і Болонський процес: Конспект лекцій. Дніпропетровськ, 2008. $34 \mathrm{c}$.

5. Лузан П. Г., Васюк О. В. Історія педагогіки та освіти: навчальний посібник. 2-ге вид., доп. і перероб. Київ, 2010. 296 с.

\section{REFERENCES}

1. Visha osvita $v$ Ukrayini: navchalnij posibnik (2005). [Higher education in Ukraine: a manual]. (Eds.). Kremen, V.G., Nikolayenko, S.M. Kyiv, 327 p. [in Ukrainian].

2. Istoriya vishoyi osviti $\mathrm{v}$ Ukrayini [History of Higher Education in Ukraine]. Available at: http://uareferat.com/[in Ukrainian].

3. Kasyanov, G. (2015). Osvitnya sistema Ukrayini 1990-2014[An educational system of Ukraine 1990-2014]. An analytical review. Kyiv, 2015. 52 p.[in Ukrainian].

4. Krivchik, G. G. (2008). Visha shkola $i$ Bolonskij proces: Konspekt lekcij [Higher School and the Bologna Process: A summary of lectures]. Dnipropetrovsk, 2008. 34 p.[in Ukrainian].

5. Luzan, P. G. \& Vasyuk, O. V. (2010). Istoriya pedagogiki ta osviti: navchalnij posibnik. 2-ge vid., dop. i pererob [History of pedagogy and education: a textbook. The 2 nd edition supplemented and redone]. Kyiv, 296 p. [in Ukrainian].

Стаття надійшла до редакції 25.04.2019 